\title{
Tolerance of Apple and Peach Trees to Triclopyr
}

Jeffrey F. Derr

Department of Plant Pathology, Physiology, and Weed Science, Virginia Polytechnic Institute and State University, Hampton Roads Agriculture Experiment Station, Virginia Beach, VA 23455

Additional index words. Malus domestica, Prunus persica, crop injury, postemergence herbicides, weed control

Abstract. The tolerance of newly planted apple (Malus domestica Borkh.) and peach [Prunus persica $(\mathbf{L}$.) Batsch] trees to the postemergence herbicide triclopyr was evaluated infield trials. Apple and peach trees were not injured by triclopyr applied at rates ranging from 0.28 to $1.12 \mathrm{~kg}$ acid equivalent (a.e.)/ha as a directed spray to soil. No injury was observed following direct application of $10 \mathrm{ml}$ of a triclopyr solution at $2 \mathrm{~g}$ a.e./liter to the lower bark of either tree species. Applications of that solution to an individual branch injured or killed the treated apple or peach branch but did not affect the rest of the tree. No reduction in tree growth or injury was noted 1 year after triclopyr application. Applications of $10 \mathrm{ml}$ of a glyphosate solution at $15 \mathrm{~g}$ a.i./liter to an apple branch caused severe injury and a growth reduction by 1 year after application, and killed all treated peach trees when applied to one branch. No triclopyr or 2,4-D treatment had affected apple or peach trunk diameter, number of branches, or tree size 1 year after application. Chemical names used: $N$ - (phosphonomethyl)glycine (glyphosate); [(3,5,6-trichloro-2pyridinyl)oxy]acetic acid (triclopyr); (2,4-dichlorophenoxy)acetic acid (2,4-D).

Control of woody perennial broadleaf weeds is an important concern in tree fruit production. There are no selective herbicides for controlling perennial broadleaf weeds such as poison ivy [Toxicodendron radicans (L.) Ktze.], Virginia creeper [Parthenocissus quinquefolia (L.) Planch.], and wild blackberry (Rubus spp.) in apple and peach plantings. Nonselective contact herbicides, such as 1, 1'dimethyl-4,4'-bipyridinium ion (paraquat), do not provide long-term control of perennials due to regrowth from root systems. Certain factors, such as overlap of optimum timing with harvest, risk of crop injury, lack of complete control, or cost, can limit use of nonselective systemic herbicides for orchard weed control. For example, glyphosate can be ap-

Received for publication 30 Apr. 1992. Accepted for publication 24 May 1993, Use of trade names does not imply endorsement of products named nor criticism of similar ones not mentioned. The cost of publishing this paper was defrayed in part by the payment of page charges. Under postal regulations, this paper therefore must be hereby marked advertisement solely to indicate this fact. plied only as a wiper application to peaches in certain states (Derr and Fey, 1992). Thus, there is a need for selective herbicides that control perennial broadleaf weeds but do not interfere with other production practices.

The objective of this study was to deteron transformed data (arcsin square root percent).

yWAT, weeks after treatment. mine the extent of apple and peach tree tolerance to triclopyr. Fruit trees have shown tolerance to triclopyr, a postemergence herbicide that controls important orchard broadleaf weeds, such as Virginia creeper (Young, 1989). Triclopyr at 0.1 to $1.12 \mathrm{~kg}$ acid equivalent (a.e.)/ha reduced ground cover by this weed in peaches (Tworkoski and Young, 1990). Virginia creeper regrew, especially at the lower triclopyr rates; however, control was acceptable with triclopyr applied at $1.12 \mathrm{~kg} \cdot \mathrm{ha}^{-1}$ for two consecutive years. Triclopyr was equally effective when applied in July, August, or September (Tworkoski and Young, 1989). Virginia creeper rooted near a tree trunk was difficult to control since its foliage was protected from the herbicide by the tree crown. The ester formulation of triclopyr was more effective than the amine formulation for Virginia creeper control (Tworkoski et al., 1988). Control was greater with high carrier volume applications due to better coverage of the dense Virginia creeper foliage.

Applications were made directly to either the bark or an individual branch, simulating exposure that could occur with either broadcast or spot-treatment applications of a postemergence herbicide for orchard weed control. The herbicides glyphosate and 2,4-D, which are registered for use on fruit trees, were included for comparison. Amine formulations of triclopyr and 2,4-D were used for all studies.

A randomized complete block with four replications was used for each experiment. Fruit trees for each study were planted in April

Table 1. Visual injury to apple and peach trees following a $10-\mathrm{ml}$ application of an herbicide solution to 15 $\mathrm{cm}$ of bark or to one branch, or herbicides applied as a directed spray to soil in three studies. ${ }^{2}$

\begin{tabular}{|c|c|c|c|c|c|c|c|}
\hline \multirow[b]{3}{*}{ Herbicide } & \multirow{3}{*}{$\begin{array}{l}\text { Appli- } \\
\text { cation } \\
\text { rate }\end{array}$} & \multirow[b]{3}{*}{ Site } & \multicolumn{5}{|c|}{ Percent injury } \\
\hline & & & \multirow{2}{*}{$\frac{1987}{\text { Apple }}$} & \multicolumn{2}{|c|}{1988} & \multicolumn{2}{|c|}{1989} \\
\hline & & & & $\begin{array}{l}\text { Apple } \\
12 \text { WAT }\end{array}$ & $\begin{array}{c}\text { Peach } \\
12 \text { WAT }\end{array}$ & $\begin{array}{c}\text { Apple } \\
7 \text { WAT }\end{array}$ & $\begin{array}{c}\text { Peach } \\
7 \text { WAT }\end{array}$ \\
\hline None & -- & -- & $7 a$ & $\overline{0 a}$ & $3 a$ & $10 a$ & $4 a$ \\
\hline \multirow[t]{5}{*}{ Triclopyr } & 2 g.liter-1 & Branch & $0 \mathrm{a}$ & $0 \mathrm{a}$ & $8 a$ & $18 \mathrm{a}$ & $18 \mathrm{~b}$ \\
\hline & 2 g.liter $^{-1}$ & Bark & $3 \mathrm{a}$ & $4 \mathrm{a}$ & $0 \mathrm{a}$ & $18 \mathrm{a}$ & $13 a b$ \\
\hline & $0.28 \mathrm{~kg} \cdot \mathrm{ha}^{-1}$ & Soil & --- & -- & -.- & $10 \mathrm{a}$ & $13 \mathrm{ab}$ \\
\hline & $0.56 \mathrm{~kg} \mathrm{ha}^{-1}$ & & --- & -- & --- & $13 a$ & $13 \mathbf{a}$ \\
\hline & $1.12 \mathrm{~kg} \cdot \mathrm{ha}^{-1}$ & & --- & --- & --- & $14 \mathrm{a}$ & $9 a b$ \\
\hline \multirow[t]{2}{*}{$2,4-\mathrm{D}$} & 5 g.liter ${ }^{-1}$ & Branch & $27 \mathrm{~b}$ & $6 a$ & $9 \mathrm{a}$ & $11 \mathrm{a}$ & $16 \mathrm{~b}$ \\
\hline & 5 g.liter $^{-1}$ & Bark & $7 \mathrm{a}$ & $3 \mathrm{a}$ & $4 a$ & $15 \mathrm{a}$ & $14 \mathrm{ab}$ \\
\hline \multirow[t]{2}{*}{ Glyphosate } & $15 \mathrm{~g} \cdot$ liter $^{-1}$ & Branch & $23 \mathrm{~b}$ & $17 \mathrm{a}$ & $100 \mathrm{~b}$ & $43 \mathrm{~b}$ & $100 \mathrm{c}$ \\
\hline & 15 g.liter $^{-1}$ & Bark & $13 a b$ & $8 \mathrm{a}$ & $75 \mathrm{~b}$ & $14 \mathrm{a}$ & $11 \mathrm{ab}$ \\
\hline
\end{tabular}

${ }^{2}$ Mean separation within columns by the Duncan multiple range test at $P \leq 0.05$. Analysis was conducted 
and fertilized with ammonium nitrate at $75 \mathrm{~g} /$ tree. The 1987 study used 'Tydeman's Red' apple on M.111 East Mailing Long Ashton (EMLA) rootstock. In the 1988 study, 'Red York' apple on M.111 EMLA rootstock and 'Blake' peach on Halford rootstock were used. The 1989 study used 'Improved Blake' peach on Halford rootstock and 'Golden Delicious' apple on seedling rootstock. For the 1990 study, 'Red Stayman' apple on M.7 EMLA rootstock and 'Redhaven' peach on certified Lovell rootstock were used.

For bark treatments, the lower $15 \mathrm{~cm}$ of the trunk was treated with $10 \mathrm{ml}$ of a $2 \mathrm{~g}$ a.e./liter triclopyr solution using a mist bottle. This simulates the concentration contained in an application rate of $0.43 \mathrm{~kg} \cdot \mathrm{ha}^{-1}$ in a spray volume of 230 liters $\cdot \mathrm{ha}^{-1}$. Ten milliliters of the same solution was misted on the foliage of a single branch of other trees. Misting minimized spray runoff to the branch base. For the 1989 and 1990 studies, triclopyr also was applied as a directed spray at $0.28,0.56$, and $1.12 \mathrm{~kg}$ a.e./ha. These treatments were applied with a $\mathrm{CO}_{2}$-pressurized backpack sprayer delivering 230 liters $\cdot$ ha $^{-1}$ using 8003 flat fan nozzles (Spraying Systems, Wheaton, Ill.). For comparative purposes, $10 \mathrm{ml}$ of either a 2,4-D amine solution at $5 \mathrm{~g}$ a.i./liter, or a glyphosate solution at $15 \mathrm{~g}$ a.i./liter was applied to either $15 \mathrm{~cm}$ of bark or to one apple or peach branch. Date, air temperature, and percent cloud cover at treatment were, respectively, 7 July 1987, 32C, and 40\%; 8 June 1988, 29C, and 0\%; 1 Aug. 1989, 29C, and $80 \%$; and 24 July 1990, 31C, and 5\%. Respective soil organic matter percentage and $\mathrm{pH}$ at the sites were: $1987,2.3 \%$ and $5.1 ; 1988,2.3 \%$ and $5.1 ; 1989,2.6 \%$ and 6.3 ; and 1990, $1.9 \%$ and 6.3.

The percentage of visual injury to the treated branch and to the rest of the tree was recorded during the growing season and 1 year after application. The most vigorous tree (no injury symptoms present), regardless of treatment, was used as the reference for visual ratings. In this manner, nontreated plants could receive a rating other than zero. For the 1990 stud y, tree height and two width measurements (the second one perpendicular to the first) per tree were taken to develop a growth index determination, $\{$ [(width $1+$ width 2$) / 2]+$ height $] / 2,1$ year after application. This growth index provided a measure of overall tree size. Trunk diameter $10 \mathrm{~cm}$ from the soil and the number of branches were also recorded for each tree. Visual ratings were converted using arcsin square root percent before analysis of variance. Means were separated using the Duncan multiple range test.

No injury was observed in nontreated parts of apple trees following soil, bark, or singlebranch exposure to triclopyr in apple (Table 1). Triclopyr injured or killed the treated apple branches and injured the treated peach branches in the 1987, 1988, and 1989 studies (data not shown). Slight injury was observed in the rest of the peach tree following branch exposure to triclopyr in 1989. Bark and soil applications of triclopyr to peach trees in 1989 caused no injury. No injury to peach was observed fol- lowing any triclopyr application to bark or a single branch in 1988. No visual injury was noted in apple or peach 1 year after triclopyr application in the 1987, 1988, or 1989 studies (data not shown).

Application of 2,4-D to a branch injured the rest of the apple tree in 1987, but injury was absent with this treatment in 1988 and 1989 (Table 1). No injury was observed in peach trees following bark application with 2,4-D. Slight injury was observed in nontreated branches following 2,4-D application to a single peach branch in 1989 , but injury was absent in 1988. As with triclopyr, 2,4-D injured the treated apple and peach branch. No injury was apparent in either species 1 year after bark or branch application of 2,4-D (data not shown).

Glyphosate caused slight to moderate injury to apple trees within 3 months of application to a branch in the 1987, 1988, and 1989 studies (Table 1). Glyphosate killed the treated branch in both species. Only glyphosate-treated trees showed injury the year after application, with injury averaging $\approx 80 \%$. Glyphosate killed all treated peach when applied to a single branch. Glyphosate applied to the bark caused severe injury to peach trees in 1988 , but did not cause injury in the other studies. Glyphosate applications to 'Shasta' peach trunks killed some of the treated trees (Putnam, 1976). The severe injury to peach noted from branch treatments matches the restrictions on use in peach orchards (Derr and Fey, 1992).

In a preliminary study, applications of triclopyr or 2,4-D to a single peach branch killed the treated branch but did not affect nontreated limbs (Majek, 1990). Glyphosate killed peach trees when a single branch was exposed in that study. Glyphosate application at 10 or $20 \mathrm{~g} \cdot$ liter $^{-1}$ to foliage severely injured peach trees (Weller and Skroch, 1983). Greater injury was observed with glyphosate applications made after 1 July than with treatments made earlier in the year. Apple and peach trees tolerated triclopyr at application timings that resulted in moderate to severe systemic injury following glyphosate treatment (Table 1). Glyphosate application at 5 or $10 \mathrm{~g} \cdot$ liter $^{-1}$ to five or 10 apple leaves injured terminal growing points (Rem et al., 1974). Glyphosate applications to the apple trunk with no foliar contact did not injure the trees.

In the 1990 study, triclopyr applications to a single branch killed the treated apple branch and injured the treated peach branch (Table 2). Injury was absent in the rest of the tree following bark, branch, or soil application of triclopyr to apple or peach. Application of 2,4-D to a single branch injured the treated apple and

Table 2. Percent visual injury to apple and peach trees 11 weeks and 1 year after a 10-ml application of an herbicide solution to $15 \mathrm{~cm}$ of bark or to one branch, or herbicides applied as a directed spray to soil in the 1990 study. $^{z}$

\begin{tabular}{|c|c|c|c|c|c|c|c|c|c|c|}
\hline \multirow[b]{3}{*}{ Herbicide } & \multirow{3}{*}{$\begin{array}{l}\text { Appli- } \\
\text { cation } \\
\text { rate }\end{array}$} & \multirow[b]{3}{*}{ Site } & \multicolumn{4}{|c|}{ Apple } & \multicolumn{4}{|c|}{ Peach } \\
\hline & & & \multicolumn{2}{|c|}{$\begin{array}{l}\text { Treated } \\
\text { branch }\end{array}$} & \multicolumn{2}{|c|}{$\begin{array}{l}\text { Rest } \\
\text { of tree }\end{array}$} & \multicolumn{2}{|c|}{$\begin{array}{l}\text { Treated } \\
\text { branch }\end{array}$} & \multicolumn{2}{|c|}{$\begin{array}{l}\text { Rest } \\
\text { of tree }\end{array}$} \\
\hline & & & $11 \mathrm{wk}$ & $1 \mathrm{yr}$ & $11 \mathrm{wk}$ & $1 \mathrm{yr}$ & $11 \mathrm{wk}$ & $1 \mathrm{yr}$ & $11 \mathrm{wk}$ & $1 \mathrm{yr}$ \\
\hline \multicolumn{11}{|c|}{ Percent injury } \\
\hline None & --- & --- & & & $0 \mathrm{a}$ & $0 \mathrm{a}$ & & & $1 \mathrm{a}$ & $4 b$ \\
\hline \multirow[t]{5}{*}{ Triclopyr } & $2 \mathrm{~g} \cdot$ liter $^{-1}$ & Branch & 100 & 95 & $0 \mathrm{a}$ & $1 \mathrm{a}$ & 60 & 63 & $1 \mathbf{a}$ & $0 \mathrm{a}$ \\
\hline & 2 g.liter ${ }^{-1}$ & Bark & & & $1 \mathrm{a}$ & $0 \mathrm{a}$ & & & $1 \mathrm{a}$ & $3 a b$ \\
\hline & $0.28 \mathrm{~kg} \cdot \mathrm{ha}^{-1}$ & Soil & & & $0 \mathrm{a}$ & $0 \mathrm{a}$ & & & $0 \mathbf{a}$ & $0 \mathrm{a}$ \\
\hline & $0.56 \mathrm{~kg} \cdot \mathrm{ha}^{-1}$ & & & & $0 \mathrm{a}$ & $0 \mathrm{a}$ & & & $0 \mathrm{a}$ & $1 \mathrm{a}$ \\
\hline & $1.12 \mathrm{~kg} \cdot \mathrm{ha}^{-1}$ & & & & $0 \mathrm{a}$ & $0 \mathrm{a}$ & & & $1 \mathrm{a}$ & $3 a b$ \\
\hline \multirow[t]{2}{*}{$2,4-\mathrm{D}$} & $5 \mathrm{~g} \cdot$ liter $^{-1}$ & Branch & 88 & 84 & $0 \mathrm{a}$ & $0 \mathrm{a}$ & 53 & 80 & $3 a$ & $3 a b$ \\
\hline & 5 g.liter-1 & Bark & & & $0 \mathrm{a}$ & $0 \mathbf{a}$ & & & $0 a$ & $0 \mathbf{a}$ \\
\hline \multirow[t]{2}{*}{ Glyphosate } & 15 g.liter $^{-1}$ & Branch & 100 & 100 & $55 \mathrm{~b}$ & $68 \mathrm{~b}$ & 100 & 100 & $100 \mathrm{~b}$ & $100 \mathrm{c}$ \\
\hline & 15 g.liter ${ }^{-1}$ & Bark & & & $0 \mathrm{a}$ & $3 \mathbf{a}$ & & & $0 \mathrm{a}$ & $0 \mathbf{a}$ \\
\hline
\end{tabular}

${ }^{2}$ Mean separation within columns by the Duncan multiple range test, $P \leq 0.05$. Analysis was conducted on transformed data (arcsin square root percent).

Table 3. Apple and peach trunk diameter, branch count, and growth index 1 year after a 10-ml application of an herbicide solution to $15 \mathrm{~cm}$ of bark or to one branch, or herbicides applied as a directed spray to the soil in the 1990 study. $^{2}$

\begin{tabular}{|c|c|c|c|c|c|c|c|c|}
\hline \multirow[b]{2}{*}{ Herbicide } & \multirow[b]{2}{*}{$\begin{array}{l}\text { Appli- } \\
\text { cation } \\
\text { rate }\end{array}$} & \multirow[b]{2}{*}{ Site } & \multicolumn{3}{|c|}{ Apple } & \multicolumn{3}{|c|}{ Peach } \\
\hline & & & $\begin{array}{l}\text { Trunk } \\
\text { diam } \\
(\mathrm{cm})\end{array}$ & $\begin{array}{c}\text { Branches } \\
\text { (no.) }\end{array}$ & $\begin{array}{c}\text { Growth } \\
\text { index } \\
\text { (m) }\end{array}$ & $\begin{array}{l}\text { Trunk } \\
\text { diam } \\
(\mathrm{cm})\end{array}$ & $\begin{array}{c}\text { Branches } \\
\text { (no.) }\end{array}$ & $\begin{array}{c}\text { Growth } \\
\text { index } \\
(\mathrm{m}) \\
\end{array}$ \\
\hline None & --- & --- & $3.2 \mathrm{a}$ & $10.3 \mathrm{a}$ & $1.6 \mathrm{a}$ & $4.1 \mathrm{a}$ & $11.8 \mathrm{ab}$ & $2.0 \mathrm{a}$ \\
\hline \multirow[t]{5}{*}{ Triclopyr } & 2 g.liter ${ }^{-1}$ & Branch & $3.2 \mathrm{a}$ & $8.0 \mathrm{a}$ & $1.7 \mathrm{a}$ & $5.0 \mathrm{a}$ & $14.3 \mathrm{a}$ & $2.4 \mathrm{a}$ \\
\hline & 2 g.liter ${ }^{-1}$ & Bark & $3.1 \mathrm{a}$ & $9.3 \mathrm{a}$ & $1.6 \mathrm{a}$ & $4.4 \mathrm{a}$ & $10.5 \mathrm{~b}$ & $2.0 \mathrm{a}$ \\
\hline & $0.28 \mathrm{~kg} \cdot \mathrm{ha}^{-1}$ & Soil & $3.4 \mathrm{a}$ & $10.5 \mathrm{a}$ & $1.6 \mathrm{a}$ & $4.6 \mathrm{a}$ & $12.0 \mathrm{ab}$ & $2.2 \mathrm{a}$ \\
\hline & $0.56 \mathrm{~kg} \cdot \mathrm{ha}^{-1}$ & Soil & $3.3 \mathrm{a}$ & $8.0 \mathrm{a}$ & $1.7 \mathrm{a}$ & $4.4 \mathrm{a}$ & $11.3 \mathrm{~b}$ & $2.1 \mathrm{a}$ \\
\hline & $1.12 \mathrm{~kg} \cdot \mathrm{ha}^{-1}$ & Soil & $3.1 \mathrm{a}$ & $9.0 \mathrm{a}$ & $1.5 \mathrm{a}$ & $4.0 \mathrm{a}$ & $11.5 \mathrm{ab}$ & $2.0 \mathrm{a}$ \\
\hline \multirow[t]{2}{*}{$2,4-\mathrm{D}$} & 5 g.liter ${ }^{-1}$ & Branch & $3.0 \mathrm{a}$ & $8.5 \mathrm{a}$ & $1.6 \mathrm{a}$ & $4.1 \mathrm{a}$ & $11.3 \mathrm{~b}$ & $2.2 \mathrm{a}$ \\
\hline & 5 g.liter-1 & Bark & $3.3 \mathrm{a}$ & $8.0 \mathrm{a}$ & $1.7 \mathrm{a}$ & $4.3 \mathrm{a}$ & $12.0 \mathrm{ab}$ & $2.0 \mathrm{a}$ \\
\hline \multirow[t]{2}{*}{ Glyphosate } & 15 g.liter ${ }^{-1}$ & Branch & $1.9 \mathrm{~b}$ & $4.3 \mathrm{~b}$ & $1.1 \mathrm{~b}$ & --- & --- & --- \\
\hline & 15 g.liter ${ }^{-1}$ & Bark & $3.0 \mathrm{a}$ & $9.0 \mathrm{a}$ & $1.5 \mathrm{a}$ & $4.3 \mathrm{a}$ & $10.5 \mathrm{~b}$ & $2.1 \mathrm{a}$ \\
\hline
\end{tabular}

${ }^{z}$ Mean separation within columns by the Duncan multiple range test, $P \leq 0.05$. Trunk diameter was recorded $10 \mathrm{~cm}$ from the soil line. Growth index was calculated using the formula $\{[$ (width $1+$ width 2$) / 2]+$ height $\} / 2$. 
peach branch. No injury was seen in the rest of the tree following apple or peach bark or branch exposure to 2,4-D.

Glyphosate applications killed the treated apple and peach branch (Table 2). Severe injury was apparent in apple 11 weeks, and 1 year, after a branch had been treated with glyphosate. Glyphosate applications to a single branch killed peach trees. Neither species was injured by bark applications of glyphosate.

No triclopyr or 2,4-D treatment affected apple or peach trunk diameter, number of branches, or growth index 1 year after application (Table 3). Glyphosate application to a single apple branch reduced trunk diameter by $41 \%$, number of branches by $58 \%$, and growth index by $31 \%$, compared to nontreated plants. No reductions were noted with bark applications of glyphosate.
Apple and peach possessed acceptable tolerance to triclopyr. Bark or branch application of triclopyr did not cause systemic injury to these species. Based on the rates used, apple and peach tolerate triclopyr better than glyphosate, an herbicide registered for use in orchards.

\section{Literature Cited}

Derr, J.F. and C.L. Foy. 1992. Chemical control of weeds, p. 84-98. In: Spray bulletin for commercial tree fruit growers. Virginia Coop. Ext. Serv. Publ. 456-419.

Majek, B.A. 1990. Phytotoxicity of several postemergence herbicides to peaches. Proc. Northeastern Weed Sci. Soc. 44:147. (Abstr.)

Putnam, A.R. 1976. Fate of glyphosate indeciduous fruit trees. Weed Sci. 24:425-429.

Rom, R.C., S.A. Brown, and J.D. Markham. 1974.
Glyphosate toxicity to apple trees. HortScience 9:594-595.

Tworkoski, T.J. and R.S. Young. 1989. Effects of rate and time of triclopyr application on Virginia creeper management in a West Virginia peach orchard. Proc. Northeastern Weed Sci. Soc. 43:138. (Abstr.)

Tworkoski, T.J. and R.S. Young. 1990. Rate and time of triclopyr application to control Virginia creeper in a peach orchard. HortScience 25:443-445.

Tworkoski, T.J., R.S. Young, and J.P. Sterrett. 1988. Control of Virginia creeper (Parthenocissus quinquefolia): Effects of carrier volume on toxicity and distribution of triclopyr. Weed Technol. 2:31-35.

Weller, S.C. and W.A. Skroch. 1983. Toxicity of glyphosate to peach trees as influenced by application timing. HortScience 18:940-941.

Young, R.S. 1989. Virginia creeper response from systemic herbicides. Proc. Northeastern Weed Sci. Soc. 43:133-137. (Abstr.) 